\title{
SPRY2 wt Allele
}

National Cancer Institute

\section{Source}

National Cancer Institute. SPRY2 wt Allele. NCI Thesaurus. Code C106028.

Human SPRY2 wild-type allele is located in the vicinity of $13 q 31.1$ and is approximately 5 $\mathrm{kb}$ in length. This allele, which encodes protein sprouty homolog 2 , plays a role in modulation of growth factor signaling pathways. 